\title{
A review of current bracken control and associated vegetation strategies in Great Britain
}

\author{
Robin J. Pakeman, Mike G. Le Duc and Rob H. Marrs
}

Pakeman, R. J., Le Duc, M. G. and Marrs, R. H. 2002. A review of current bracken control and associated vegetation strategies in Great Britain. - Web Ecol. 3: 6-11.

Bracken is a major problem for livestock-based, extensive agriculture in many parts of the world. It also causes problems for conservation, recreation, game management and forestry and is hence subject to management in order to control it. This paper reviews current bracken control strategies in Great Britain to assess whether they can be improved, and reviews recent work on combining bracken control with vegetation restoration to derive guidelines for maximising the cost-effectiveness of these measures to increase biodiversity.

Bracken control in Great Britain is currently, mainly undertaken by aerial spraying of herbicide. A large-scale survey showed that only a small proportion (25\%) of sites were likely to show long-term control, the developing vegetation was not that desired by the instigator of control, and there was a large geographic variation in success. The major conclusion was that large-scale treatment often exceeded the area that could be adequately treated by follow-up measures.

Experimental studies demonstrate that to obtain "desirable" vegetation (usually Calluna vulgaris-dominated heath in Great Britain) a number of steps usually have to be followed. However, the steps that have to be taken may differ between sites. Deep litter sites, where stock numbers are low, need the litter disturbed in some way and seed of suitable species added. On sites with higher stock numbers, litter disturbance has in effect already been carried out, so that management must involve seed addition and the exclusion/reduction of stock. It is not yet known how long or to what level stock must be removed before the vegetation is able to withstand grazing. It should be noted that management to reverse succession could prove less cost-effective than management that accelerates succession to woodland or forestry.

A set of points which highlight the considerations necessary at the commencement of an "integrated" bracken control programme are outlined. Targeting sites in western Britain or sites with residual vegetation present would provide the greatest gains for biodiversity in the short term. However, in many situations management for vegetation restoration must be seen as a key part of this strategy, not as something that will proceed unaided after bracken control has taken place.

R. J.Pakeman (r.pakeman@mluri.sari.ac.uk), Macaulay Land Use Research Inst., Craigiebuckler, Aberdeen, U.K. AB158QH. - M. G. Le Duc and R. H. Marrs, School of Biological Science, Derby Building, Liverpool Univ., Liverpool, U.K. L69 3BX.

Accepted 28 February 2001 
Since the traditional industrial and agricultural uses of bracken have declined (Rymer 1976), bracken Pteridium aquilinum (L.) Kuhn has been seen as a significant problem affecting farming, conservation forestry and amenity in oceanic areas of Europe, and particularly in Great Britain (Pakeman et al. 1996). It has also become a major problem in many areas of the world, particularly as a weed of pastures in areas as diverse as the Azores, Australia, Costa Rica, New Zealand and Venezuela (Thomson and Smith 1990).

In countries where summer forage other than bracken is sufficient, the problems associated with bracken are largely a consequence of replacement of grazing land, tick-borne diseases (bracken litter provides a good tick habitat), interference with tree regeneration, replacement of habitats important for conservation, and as a hindrance to recreational activities (Pakeman and Marrs 1992, Pakeman et al. 1996). In other parts of the world, where bracken forms a larger part of the diet of grazing livestock because other forage is limited, veterinary problems can be acute. Toxicity is often the main problem, but carcinomas of the oesophagus, gut and bladder are also common (Smith 1990). There is some evidence that the carcinogen can be passed on in milk (Villalobos-Salazar et al. 1990). As a result of this interference with other land uses, bracken has been subject to various control measures. These have mainly focussed on removing biomass (cutting or rolling of fronds) or the use of herbicides to reduce frond production. Both methods effectively work to reduce rhizome reserves of buds and carbohydrate (Pakeman and Marrs 1994).

This paper reviews the effectiveness of the major current means of bracken control in Great Britain (herbicide application) in terms of its effects on the target plant and in terms the vegetation that replaces bracken, and comments on the shortcomings of current practice. The paper also reviews recent research on integrating bracken control with vegetation restoration and management to achieve long-term gains in biodiversity. A set of issues that need to be considered during the development of a bracken control strategy are put forward.

\section{An analysis of current herbicide control strategies in Britain}

At present, herbicide application appears to be used over greater areas than mechanical methods of control in Great Britain. The predominant herbicide used on bracken, asulam, is licensed for aerial spraying. As a consequence, detailed records are kept about the extent of spraying (Wardman and Thomas 1998). Between 1980 and 1998 a total area of $845 \mathrm{~km}^{2}$ was sprayed. This represents ca $20 \%$ of the land area of dense bracken occurring in the open Great Britain (Barr et al. 1993), and a considerable investment of ca $£ 12000000$ at 1999 prices. When all bracken control is taken into account, i.e. ground based spraying and repeated mechanical control, then a considerable amount of money and effort is spent in control over a large proportion of the extent of bracken. However, a survey of 102 sites where bracken had been controlled by aerial spraying and 15 unsprayed sites revealed a number of problems with this approach (Le Duc et al. 2000).

"Poor control": missed strips and poor herbicide uptake (often as a result of rain) result in many areas that need respraying. Apart from this, only ca $25 \%$ of sites surveyed showed long-term or likely long-term control of bracken. At the remaining $75 \%$ of sites, bracken regeneration towards dominance appeared to be proceeding (Pakeman et al. 1998).

"Undesirable replacement vegetation": the target of the majority of control measures is some form of heather (Calluna vulgaris (L.) Hull)-dominated community for the purposes of game management, conservation or amenity as well as for grazing. Out of the 102 sites sprayed, only 17 could be described as heathland (Table 1), whereas 73 sites were categorised as grassland. The main dominant species were Deschampsia flexuosa (L.) Trin., Agrostis capillaris (L.), Festuca ovina (L.) and Nardus stricta (L.). Those grasslands dominated by $D$. flexuosa and $N$. stricta are of little use agronomically, and much lower in conservation value than heathland (Pakeman and Marrs 1992).

Grazing is a major determinant of the direction of vegetation change after control. For example in moorland situations, high sheep grazing levels result in a moss carpet dominated by Campylopus introflexus (Hedw.) Brid., and low grazing results in a grassy vegetation dominated by $D$. flexuosa. The desired dominant C. vulgaris rarely dominates, and only at intermediate grazing pressure (Pakeman et al. 1997, Le Duc et al. 2000).

"Geographical variation": the rate and direction of vegetation succession at these 102 sites was highly correlated with longitude, latitude and distance from the sea (Le Duc et al. 2000). Sites in western Britain (and coastal sites) showed a more diverse (Fig. 1) and also a more rapid increase in vegetation cover than sites in eastern and central Britain. This may be a consequence of a higher species pool or the more rapid breakdown of litter in the wetter climate of western Britain. However, spraying activities to date have been concentrated on the drier eastern and central areas as they experience more suitable flying days, grouse Lagopus lagopus scoticus shooting is more important so economic returns are higher, and some authorities have paid extra grants to promote control (Anon. 1991).

"Follow-up treatment": what this study and many others have emphasised is that aerial spraying is only the first stage in a programme of control. The developing vegetation needs to be managed and bracken needs to be subject to continuing follow-up treatment to maintain control and protect the initial investment in the aerial spraying (Pakeman et al. 2000a). Spot spraying should be carried out every year to ensure control is maintained, though at 
Table 1. Vegetation types (major groups and communities) of the National Vegetation Classification (Rodwell 1991a, b, 1992) that were present on the 117 sites surveyed during the national assessment of bracken control by aerial spraying.

\begin{tabular}{lc}
\hline Major grouping & Number of occurrences \\
NVC community & \\
\hline Woodland/scrub & 8 \\
Calcicolous grassland & 1 \\
Mesotrophic grassland & 1 \\
Calcifugous grassland & 71 \\
U1 Agrostis capillaris-Festuca ovina-Rumex acetosella grassland & 9 \\
U2 Deschampsia flexuosa grassland & 31 \\
U3 Agrostis curtisii grassland & 1 \\
U4 Agrostis capillaris-Festuca ovina-Galium saxatile grassland & 18 \\
U5 Nardus stricta-Galium saxatile grassland & 12 \\
Heathland & 17 \\
H1 Calluna vulgaris-Festuca ovina heath & 1 \\
H8 Calluna vulgaris-Ulex gallii heath & 3 \\
H9 Calluna vulgaris-Deschampsia flexuosa heath & 3 \\
H12 Calluna vulgaris-Vaccinium myrtillus heath & 4 \\
H18 Vaccinium myrtillus-Deschampsia flexuosa heath & 5 \\
H21 Calluna vulgaris-Vaccinium myrtillus-Sphagnum capillifolium & 19 \\
Bracken (U20) & 19 \\
\hline
\end{tabular}

one test site (Carneddau, SH692713) initial control was good enough to keep bracken suppressed at low levels until follow-up treatments were implemented three years after the initial spraying in 1993 (Le Duc et al. 1999). Despite the initial control being very effective, after five years frond mass $(+\mathrm{A}-\mathrm{F})$ had increased substantially to $17 \%$ of the untreated control $(-\mathrm{A}-\mathrm{F})$. Spot spraying $(+\mathrm{A}+\mathrm{F})$ had reduced frond mass to only $0.2 \%$ of the control (two years after follow-up treatment), substantially prolonging the period in which vegetation can establish without competition from bracken (Fig. 2).

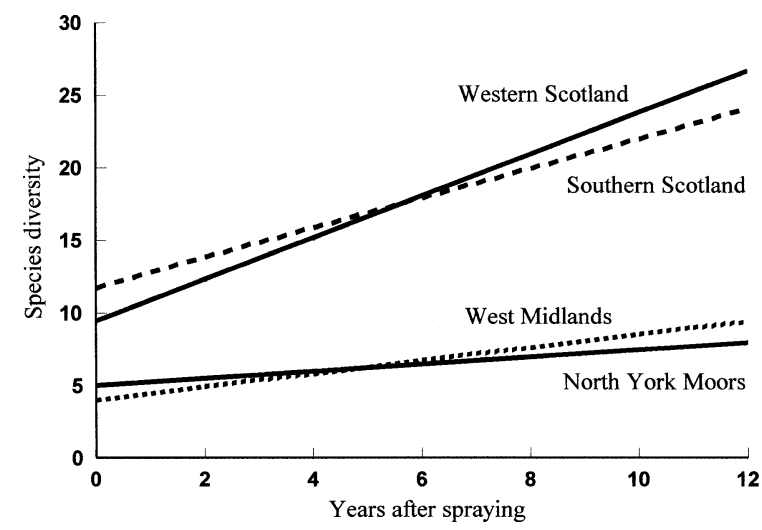

Fig. 1. Changes in site species diversity $\left(\mathrm{N}_{2}\right.$, Hill 1973) in four regions of Great Britain. Lines represent best-fit regression equations for clarity.

\section{Establishing vegetation and directing succession}

The large-scale survey described above and previous work (Marrs and Lowday 1992, Pakeman et al. 1997) highlighted the major impediments to the development of desirable vegetation. Basically, these are interference from the regenerating bracken, reduction in germination and establishment by the litter layer, an absence of propagule bank, and selective grazing by livestock. Except for interference from the bracken canopy (addressed above), these are dealt

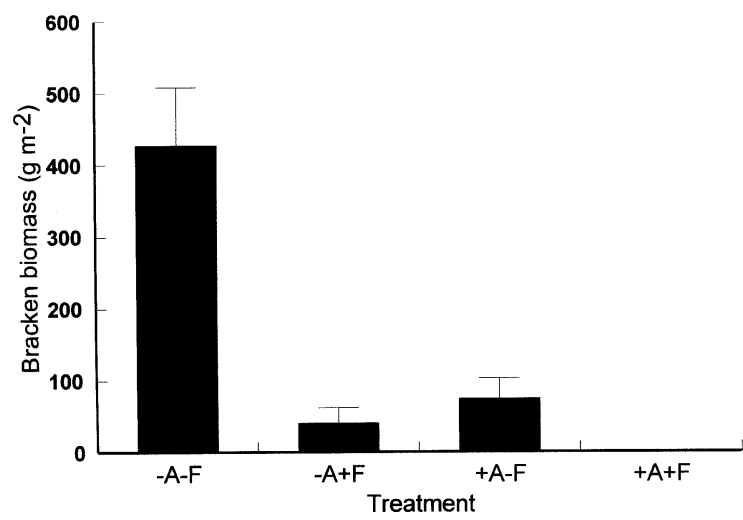

Fig. 2. The effects of herbicide spraying (asulam, + A) in 1993, and follow-up spraying $(+\mathrm{F})$ in 1996 , on the mean biomass $( \pm 1$ $\mathrm{SE}, \mathrm{n}=27$ ) of bracken in 1998 at Yr Orsedd, Carneddau. 
with in turn with reference to the restoration of a $C . v u l-$ garis-dominated community. The experiments reported here represent a small part of an integrated study focussed on determining appropriate, cost-effective methods for bracken control and vegetation restoration in the uplands and upland margins of Great Britain (Le Duc et al. 1999).

"Bracken litter": a number of methods are possible to prevent litter hindering plant establishment and growth; mechanical removal, incorporation into the soil, and burning. All serve the same purpose of providing a seedbed for germination. In one experiment (Hordron Edge, Derbyshire, SK 214868) on a deep litter site, the removal of litter $(-\mathrm{L})$ increased the mean cover of $C$. vulgaris over the course of the experiment $(\mathrm{p}=0.012)$. After five years $C$. vulgaris cover was $90 \%$ higher (Fig. 3 ) and the mean vascular plant cover was $130 \%$ higher $(\mathrm{p}=0.003,5.5$ vs $13.1 \%)$ on the $-\mathrm{L}$ plots. Despite litter clearance, vegetation growth at this site has been slow (Pakeman et al. 2000b).

"Propagule addition": many bracken-dominated sites have been demonstrated to have depauperate seedbanks, both in terms of number and diversity (Pakeman and Hay 1996, Le Duc et al. 1999). It has previously been demonstrated in lowland heathland sites, that heather addition is necessary to ensure establishment (Marrs and Lowday 1992). In two separate experiments (Pakeman et al. 2000b), the addition of heather seed in the form of cut shoots with seed heads intact at the rate of $5 \mathrm{t} \mathrm{ha}^{-1}$, was sufficient to establish heather. At the deep litter site (Hordron Edge), seeding $(+S)$ increased heather cover by $430 \%(\mathrm{p}=0.015)$ and there was a substantial interaction with litter removal $(p=0.039)$, so that the highest cover of C. vulgaris was on the $+\mathrm{L}+\mathrm{S}$ treatment (Fig. 3). At a site where grazing animals and wind had removed much of the litter after control (Wetherhouse Moor, N. Yorkshire, SE 550940), C. vulgaris establishment was considerably higher (Fig. 4). After 5 yr C. vulgaris cover was $250 \%$ higher on sown plots $(+S)$ than on the unsown plots $(\mathrm{p}=0.016)$.

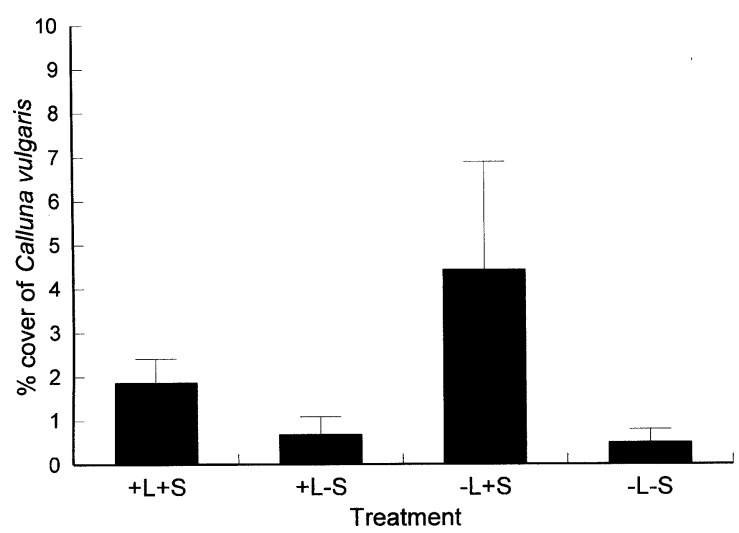

Fig. 3. The effects of litter disturbance $(-\mathrm{L})$ and Calluna vulgaris seed addition $(+S)$ on the mean cover $( \pm 1 \mathrm{SE}, \mathrm{n}=16)$ of $C$. vulgaris five years after treatment at Hordron Edge.
Where a nurse crop (Agrostis castellana and Deschampsia flexuosa) had been sown to aid establishment, cover was lower due to competition, as the nurse crop proved more vigorous than expected. In the majority of cases where bracken has been dominant for any length of time, seed of C. vulgaris must be added to achieve a heathland community (Pakeman and Hay 1996). Otherwise, the developing vegetation of the site will be one dominated by a range of grass species with a lower value for conservation.

"Grazing management": what Fig. 4 also shows is that the presence of grazing animals $(+G)$ has a considerable effect on the development of heather cover (Pakeman et al. $2000 \mathrm{~b})$. The cover of $C$. vulgaris was approximately ten times higher within the grazing exclosure $(\mathrm{p}=0.039)$, with very low covers recorded where grazing animals (ca 2 sheep $\mathrm{ha}^{-1}$ ) had access. The most successful treatment was where grazing animals had been excluded and seed of heather added, though the interaction term was not significant $(\mathrm{p}$ $=0.076$ ).

Contrasting the two sites (Hordron Edge and Wetherhouse Moor) illuminates a problem for management of sites after control. Grazing animals serve to break up the litter and, to some extent, prevent bracken regeneration (Sparke 1985, Pakeman et al. 1997). Five years after the start of the experiment, bracken cover was $9.5 \%$ inside the exclosures at Wetherhouse Moor compared to $0.7 \%$ outside, though the difference was not significant. However, high densities of grazing animals effectively prevent the establishment of $C$. vulgaris. Conversely, the absence of grazing animals hinders litter breakdown, and means that considerable effort must be made into removing this barrier to establishment, if large areas of unsightly litter are not considered suitable from a aesthetic point of view. If sloping, these bare areas may be a focus for the start of soil erosion. Controlling stock numbers in range grazing systems is often expensive (primarily fencing costs) or even not possible under some policy restrictions.

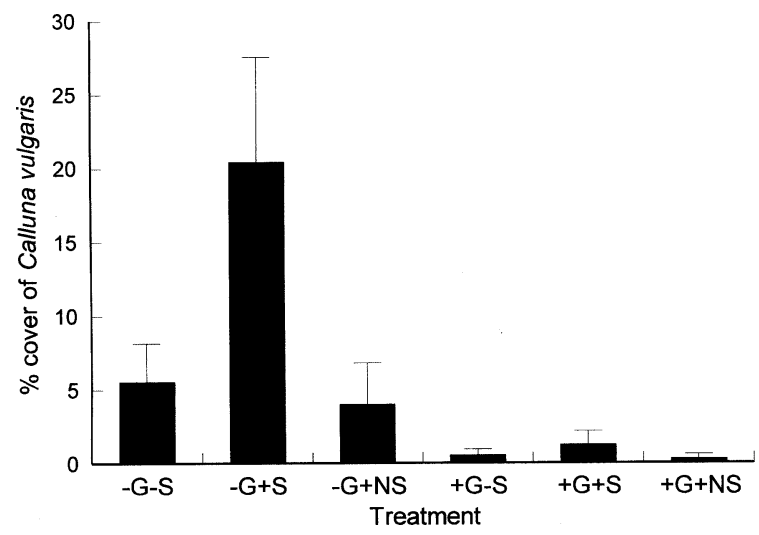

Fig. 4. The effects of grazing exclusion $(-G)$, seed addition of Calluna vulgaris $(+\mathrm{S})$, and addition of a nurse crop seed (Deschampsia flexuosa, $+\mathrm{NS})$ on the mean cover $( \pm 1 \mathrm{SE}, \mathrm{n}=16)$ of $C$. vulgaris five years after treatment at Wetherhouse Moor. 
The optimal strategy may have to be tailored for each site. Deep litter sites may require disturbance of the litter, possibly by temporarily stocking with high numbers, and seed addition. On shallow litter sites with high stock numbers, these must be reduced or removed. Fencing for a short period (3-5 yr) may be sufficient to establish a cover of heather before stock are allowed access. This is currently under test.

The previous paragraphs have dealt with the operations necessary to ensure that a bracken control programme would produce a "plagioclimax", a C. vulgaris-dominated community that needs to maintained by management (grazing, burning). Bracken invasion of grassland and heathland sites is regarded as an advance in successional terms. A more sustainable strategy, in the sense of reduced inputs, would be to accelerate succession to some form of woodland or forestry (Marrs et al. 2000). This would be the long-term future for a bracken stand, where a suitable source of propagules was nearby, and where grazing livestock were excluded. There is relatively little information available on the effects of bracken competition on developing tree seedlings and saplings. However, it appears that establishment and growth are better where the bracken is controlled (Paterson 1996, Humphrey and Swaine 1997). Current conservation strategies in the upland and upland margins of Great Britain are often aimed at increasing the cover of woodland (Anon. 1995).

\section{An integrated control programme}

Current understanding shows that bracken control is not a simple problem, but must be seen as a continuing land use/management strategy. The greatest short-term gains in biodiversity can be made if control is targeted where diversity is likely to increase quickly (western Britain) or on sites where a diverse range of species are already present. This latter effectively means prioritising areas for control where bracken has recently invaded other communities or where it is not completely dominant for other reasons.

Wherever bracken control is carried out, a land management strategy must address the following:

1) Effects of control on the current biodiversity and land use. For example, control should not be attempted on sites which contain species of conservation interest or where stock trampling might encourage erosion.

2) Effects of control on neighbouring sites, as they may contain herbicide sensitive species. Spray drift of asulam can affect the growth and survival of other fern species.

3) What is the objective? Is the target appropriate and how will it be managed in the future? Management for the target vegetation should not conflict with the management of neighbouring areas, especially if the area controlled is part of a large management unit.

4) What are the advantages, disadvantages and likely success of the different control methods? Consideration of all the options is necessary, and the most obvious course of aerial spraying may not be the most cost-effective.

5) Resources must be available for follow-up treatment. All land treated should have control followed-up. Past control programmes may have failed because they were too ambitious, as too large an area was treated to allow for effective follow-up treatment of regenerating bracken. Grant support should be dependent on follow-up being undertaken.

6) What resources are available for establishing/managing subsequent vegetation cover? For example, can heather seed be collected from the same farm/estate or does it need to be purchased. Can the litter be removed mechanically, or is a team of people necessary to carry out a controlled burn. Follow-up and after-care management costs must be included as part of the economic planning of a control programme.

7) Is the option of reversing succession to grassland or heathland the most cost-effective, the most suitable in terms of landscape or biodiversity, or the most sustainable? Accelerating succession to woodland may be a better longterm option.

Adoption of this broad strategy will offer the probability of long-term, sustainable future land use. A set of guidelines, aimed at practitioners, adaptable to different situations and sites has been produced that takes into account these options (Le Duc et al. 1999). Developing a coherent strategy for bracken control is, however, only part of the issue. A greater understanding of the ecology of bracken and the factors that contribute to its spread and dominance needs to be gained before it can be maintained at an appropriate level in the landscape. Not only must this understanding contribute to bracken management in Great Britain, but it must be applicable to other areas of the world, particularly where animal and human health issues are of major concern.

Acknowledgements - This work was funded by the U.K. Ministry of Agriculture, Fisheries and Food.

\section{References}

Anon. 1991. Moorland Management Programme 1985-1990. North York Moors National Park, Helmsley.

Anon. 1995. Biodiversity: The UK Steering Group Report. Vol. 2: Action plans. - HMSO, London.

Barr, C. J. et al. 1993. Countryside Survey 1990: Main Report. Countryside 1990 Series: Vol. 2. Dept Environ., London.

Hill, M. O. 1973. Diversity and evenness: a unifying notation and its consequences. - Ecology 54: 427-432.

Humphrey, J. W. and Swaine, M. D. 1997. Factors affecting the natural establishment of Quercus in Scottish oakwoods. I. Competition from Pteridium aquilinum. - J. Appl. Ecol. 34: 577-584. 
Le Duc, M. G. et al. 1999. Integrated bracken control and vegetation restoration: ongoing assessment with follow-up treatments. - Rep. to Ministry of Agriculture, Fisheries and Food. Univ. Liverpool, Liverpool.

Le Duc, M. G., Pakeman, R. J. and Marrs, R. H. 2000. Vegetation changes after treatment for bracken (Pteridium aquilinum) control, by herbicide, on upland and marginal areas of Great Britain. - J. Environ. Manage. 58: 147-160.

Marrs, R. H. and Lowday, J. E. 1992. Control of bracken and the restoration of heathland. II. Regeneration of the heathland community. - J. Appl. Ecol. 29: 204-211.

Marrs, R. H. et al. 2000. The ecology of bracken: its role in succession and implications for its control. - Ann. Bot. 85 (Suppl.) B: 3-16.

Pakeman, R. J. and Marrs, R. H. 1992. The conservation value of bracken, Pteridium aquilinum (L.) Kuhn, dominated communities in the UK, and an assessment of the ecological impact of bracken expansion or its removal. - Biol. Conserv. 62: 101-114.

Pakeman, R. J. and Marrs, R. H. 1994. The effects of control on the biomass, carbohydrate content and bud reserves of bracken (Pteridium aquilinum (L.) Kuhn), and an evaluation of a bracken growth model. - Ann. Appl. Biol. 124: 479493.

Pakeman, R. J. and Hay, E. 1996. Heathland seedbanks under bracken Pteridium aquilinum (L.) Kuhn and their importance for re-vegetation after bracken control. - J. Environ. Manage. 47: 329-339.

Pakeman, R. J. et al. 1996. The bracken problem in Great Britain; its present extent and future changes. - Appl. Geogr. 16: 65-86.

Pakeman, R. J., Le Duc, M. G. and Marrs, R. H. 1997. Moorland vegetation succession after the control of bracken with asulam. - Agricult. Ecosyst. Environ. 62: 41-52.

Pakeman, R. J., Le Duc, M. G. and Marrs, R. H. 1998. An assessment of aerially applied asulam as a method of long-term bracken control. - J. Environ. Manage. 53: 255-262.
Pakeman, R. J., Marrs, R. H. and Le Duc, M. G. 2000a. Bracken distribution and control methods: their implications for the sustainable management of marginal land in Great Britain. Ann. Bot. 85 (Suppl.) B: 37-46.

Pakeman, R. J. et al. 2000b. Vegetation restoration on land previously subject to bracken control by herbicide. - Appl. Veg. Sci. 3: 95-104.

Paterson, S. 1996. Control and modelling of bracken (Pteridium aquilinum (L.) Kuhn) in Great Britain. - Ph.D. thesis, Univ. Liverpool.

Rodwell, J. S. 1991a. British plant communities. Vol. 1. Woodlands and scrubs. - Cambridge Univ. Press.

Rodwell, J. S. 1991b. British plant communities. Vol. 2. Mires and heaths. - Cambridge Univ. Press.

Rodwell, J. S. 1992. British plant communities. Vol. 3. Grassland and montane communities. - Cambridge Univ. Press.

Rymer, L. 1976. The history and ethnobotany of bracken. - Bot. J. Linn. Soc. 73: 151-176.

Smith, B. L. 1990. Bracken fern and animal health in Australia and New Zealand. - In: Thomson, J. A. and Smith, R. T. (eds), Bracken biology and management. Aust. Inst. Agricult. Sci. Occas. Publ. No. 40, Sydney, pp. 227-232.

Sparke, C. J. 1985. Effect of after-treatments on sward composition and the establishment of introduced species following the control of bracken. - Grass For. Sci. 40: 403-409.

Thomson, J. A. and Smith, R. T. 1990. Bracken biology and management. - Aust. Inst. Agricult. Sci. Occas. Publ. No. 40, Sydney.

Villalobos-Salazar, J., Meneses, A. and Salas, J. 1990. Carcinogenic effects in mice of milk from cows fed on bracken fern Pteridium aquilinum. - In: Thomson, J. A. and Smith, R. T. (eds), Bracken biology and management. Aust. Inst. Agricult. Sci. Occas. Publ. No. 40, Sydney, pp. 247-252.

Wardman, O. L. and Thomas, M. R. 1998. Pesticide usage survey report 149. Aerial applications, United Kingdom 1997. - Ministry of Agriculture, Fisheries and Food, London. 